\title{
The Gaps of Environmental Criminal Liability in Armed Conflicts and its Consequences: An Analysis under Stockholm, Geneva and Rome
}

\section{Dombrowski VCK}

Environmental researcher, L.LM Law, State and Society (UFSC), Bachelor in Law and Specialist in Environmental Law (PUC-PR), Curitiba, Paraná, Brazil

"Corresponding author: Dombrowski VCK, Environmental researcher, L.LM Law, State and Society (UFSC), Bachelor in Law and Specialist in Environmental Law (PUC-PR), Curitiba, Paraná, Brazil, E-mail: vivian_ dombrowski@yahoo.com

Citation: Dombrowski VCK (2016) The Gaps of Environmental Criminal Liability in Armed Conflicts and its Consequences: An Analysis under Stockholm, Geneva and Rome. J Forensic Sci Criminol 4(4): 401. doi: 10.15744/2348-9804.4.401

Received Date: May 25, 2016 Accepted Date: August 29, 2016 Published Date: August 30, 2016

\begin{abstract}
Armed conflicts have always meant the ultimate expression of power and at the same time, lack of understanding among nations. Cities were destroyed, people were killed, and assets were devastated. But these are not only the loss of a war: the environmental damage comes to be considered immeasurable losses in the short, medium and long term. And this is because no nation wants to bear that cost. They invest in military equipments, trainings, technical equipments but the environmental account yet finds gaps in international law. Considering such a generalization in rights protection, many nations are at imminent danger in a conflict if the water will be used as a mass weapon, especially if we consider important rivers such as Jordan, Euphrates and Nile. The top three international documents were analyzed on the subject: the Stockholm Convention (1972), Additional Protocol I to the Geneva Convention (1977) and the Rome Statute (1998). Indeed, some references are researched in doctrine, especially scientific articles, to substantiate with consistent data about the extent of the damage, historical factors and decisions which have been successful. However, due to the lack of literature about this subject, the research tends to be exhaustive. From the study of the indicated material, it was noted that international law - humanitarian and environmental - calls in some of its instruments the environmental protection in war conflicts, but they are generic and vague rules that do not define exactly what is the environmental damage, nor sets standards for measure them. Taking into account the mains conflicts of the century XX: World War II, the Vietnam War and the Gulf War, one must realize that the environmental consequences were of great rides - never deactivated landmines, buried nuclear weapons, armaments and munitions destroyed in the soil, chemical weapons, not to mention the effects of some weapons when used (uranium, agent Orange, etc). Extending the search for more recent conflicts such as Afghanistan, it is proven that the effects on health of the civilian population were catastrophic: cancer, birth defects, and deformities in newborns. There are few reports of nations that, somehow, repaired the damage caused to the environment as a result of the conflict. In the pitch of contemporary conflicts, many nations fear that water resources are used as weapons of mass destruction, because once contaminated - directly or indirectly - can become a means of disguised genocide side effect of military objective. In conclusion, it appears that the main international treaties governing the subject mention the concern for environmental protection, however leave the normative specifications vacancies necessary to effectively there is a prevention of environmental damage in armed conflict and, should they occur, the repair of the same. Still, it appears that there is no protection mechanism to safeguard natural resources and avoid them to become a mass destruction weapon.
\end{abstract}

Keywords: Environmental damages; Humanitarian Law; Armed conflicts; Criminal liability; Ecocide

\section{Introduction}

War is always a synonym of destruction and pain and there is no different result of an armed conflict. The damages caused by the armed conflict sometimes do not have a specific protection under the law. There are some international documents about this issue however they do not establish the liability of each nation involved in an armed conflict, what allow a lack of punishment to the countries that use mass weapons. An analysis under the three important international documents in this field: Stockholm Convention, Additional Protocol I to the Geneva Convention and Rome Statute will be done to find if there are the gaps of liability, what they are and the risks to the environment during and after an armed conflict, mainly about the water resources, considering there is important rivers in conflict zones' boundaries.

\section{Materials and Methods}

In this article it was done an extensive research in documents, books and articles about the environmental consequences of an 
armed conflict, which are the liabilities of belligerent's states, the international documents about the theme and the damages to the environment, especially the water resources in boundaries' zone.

\section{Documents}

They were used to support the research and to provide legal and regulatory protection. Once international relations are governed by treaties and agreements between the member states, the documents constitute the north of relations, including in the state of war.

- United Nations Declaration on the Human Environment, Stockholm, 1972 (Stockholm Convention).

- Protocol Additional to the Geneva Conventions of 12 August 1949, and relating to the Protection of Victims of International Armed Conflicts (Protocol I), ILM 1391, (1997).

- Rome Statute, 1998.

- 1907 Hague Convention IV, Respecting the Laws and Customs of War and Land (with Annexed Regulations).

\section{Books}

There are not a lot of books about the article's theme. What could be used were some doctrines about international relations, public international law, environmental law and from them taking some concepts to support the main idea.

- A. Montagu, A natureza da agressividade humana. Rio de Janeiro: Zahar Editores.

- C. Mello, Direitos humanos e conflitos armados. Rio de Janeiro: Renovar, 1997.

- J. Spanier, Games nations play. Congressional Quarterly Press, 1996.

- C. Tilly, Coerção, capital e Estados europeus. São Paulo: Edusp, 1996.

- C. Swinarski. Introdução ao direito humanitário internacional. Brasilia: Escopo, 1988.

- M. Young, The Techincal Writers Handbook. Mill Valley, CA: University Science, 1989.

- E. Koppe. The use of nuclear weapons and the protection of the environment during international armed conflict.

Oregon: Hart Publishing, 2008.

- V. Dombrowski. Practical-theory aspects of urban environmental Law. Dissertation. Florianópolis: Federal University of Santa Catarina, 2011.

- M. Zeitoun. Power and Water in the Middle East: The Hidden Politics of the Palestinian-Israeli Water Conflict.

London, GBR: I.B. Tauris, 2008. ProQuest ebrary.

\section{Articles and Reports}

Articles were used in this research to give some support or just to complement some idea.

- United Nations Environment Program- Protecting the environment during armed conflict. An inventory and analysis of international Law. 2009.

- AL-DUAIJ, Nada. Environmental Law of Armed Conflict. Dissertation. Pace University School of Law. 2002.

- United Nations Interagency Framework Team. Toolkit and Guidance for Preventing and Managing Land and Natural Resources Conflicts. Renewable resources and conflicts.

- J. U. Duncombe, "Infrared navigation-Part I: An assessment of feasibility (Periodical style)," IEEE Trans. Electron

Devices, vol. ED-11, pp. 34-39, Jan. 1959.

- UN-Water. World Water Day 2015.

- UN Water - United Nations Inter-Agency in mechanism in all fresh water related issues including sanitation.

Transboundery waters : UN-Water paper sharing benefits, sharing responsability, 2008 ; UNESCO, 2013.

\section{Results}

After the studying and researching, as the analyzes and doctrine material review about the environmental damage caused in armed conflicts and the liability of the belligerents, it could be perceived some points that concerns especially nowadays when natural resources are becoming.

From the legal documents review is possible to perceive that there are some "lacks" or empty concepts that should be more specific as the concept of "damage" and, of course, its extension. It is hard to talk about environmental damages if there is not a complete definition about it, indeed, how can be its extension. The international conventions, treats and United Nation documents just mention some concepts but they should be more detailed in order to avoid some misunderstanding or, even worst, nonpunishment for who commit some crime in this field.

Still, the international environmental law and humanitarian law should contain specific regulation about liability of the belligerents and the consequences and punishments for who commit some environmental damage during an armed conflict.

Throughout history, a lot of damage has been caused and no one has been paid for them. During the Second World War, bombs, military arms, orange agent and landmines were used and damaged the soil and the water. And it is not just about the World War. Every conflict that uses guns, bombs, explosives or some chemical substance is damaging the environment. 
In the global warming age, natural resources are fast depleting and some of them are turning in exchange, increasing their value and becoming a power resource. Water, for example, has been motive of serious conflicts especially in Middle East and Africa, where some important rivers are located and in poor or disputed lands.

Unfortunately it was not possible to do a field work and to see in loco the extension of these damages, how people and environment have been suffering. Nevertheless, it is intending to go ahead with this research and, some time, go to the field and prove with own data (not just reviews, analyzes, readings) why the law should be more tough about it.

\section{Discussions}

\section{Armed Conflict Context}

Armed conflict has been the subject of study and research since the earliest times. The fight, the competition and the power are inherent in the human being. Since the beginning, the primate man was already involved in conflicts for possession of land, space or food. It is clear, therefore, that many disputes were always around things from nature.

Human behavior has always been analyzed as part of the conflict, that is, the fact of violence is genetically determined or if all individuals are able to develop certain behavior. In this sense, there is the thesis of Montagu, who teaches that " [...] no specific human behavior is genetically determined; that humans are able to express any type of behavior, not only aggressive but also selfishness kindness, cruelty, tenderness, nobility, cowardice, joy, etc" [1]. He also explains that an aggressive behavior is just another in a long line, and any explanation of human behavior should explain all behaviors, not just one of them. In this way, the behavior of a human being in any event is not determined by your genes, although obviously there is a genetic contribution, but most of the experiences that have accumulated throughout his life is in integration with these genes and contribute to build his character.

Although there is no conclusion about the war instinct of human beings, many sociological streams argue that such instinct is present in man and that it can be triggered by cultural and educational factors, as well as passion. Domestic environment, family relationships, school education are factors that could contribute to an individual's personality development still in its childhood, and that he will carry throughout your life. Violent parents, inattentive teachers, bullying, feelings of abandonment, might wake the child's violent behavior.

Later, this issue also extended up to religion, where many of them are set in theirs holy books (Bible, Koran) determinations about the war, the protection of civilians and even the environment. For religion, human behavior reflects your character and up to the individual continuous improvement and the spread of peace. The soil and environment's concern could be seen in Deuteronomy, Exodus, and Hebrews in the Bible, what reflects a behavior still in the Old Testament [2].

However, there is no definition of "armed conflict". War can be not defined merely as the absence of peace, since the international documents allow the war if the subject is legal and compatible with the dispute. Some authors define armed conflict as: any disagreement involving the use of weapons between two or more nations, such as national civil wars, or international parties such as international armed conflicts. The Criminal Tribunal for the Yugoslav also defined as an armed conflict exists whenever there is a resort to armed force between States or protracted armed violence between governmental authorities and organized armed groups or between such groups within the State, which means that It can be recognized even it will not nation against nation.

Just as there is not an exact concept for armed conflict, there is also not an exactly definition of the reasons that lead a conflict. Mello believes that everything can lead to a war, and all can lead for that it does not occur [3]. Some common reasons for its development can be: cultural, political, economic, ethnic, religious. But in all conflicts, the political question is present and motivates the conflict and makes its inception possible.

Spanier said that "human beings may well be alike, in spite of their different languages, clothing, and mannered. But politics starts where the commonalities of humanity stop, and it starts here because of the different interests, values, ideologies, and histories of the many nation states. All want peace-but only on their terms"[4].

Just for recording, there's an idea of the accounting of war throughout history: between 1480 and 1800, every 2 or 3 years, broke out a significant international conflict; between 1800 and 1944, either or 2 years; and from the Second World War, every 14 months a new conflict began, featuring the twentieth century as the most warlike of human history [5].

This is also due to technological advancement, which led to the invention and spread of new weapons, including nuclear. The weapons have become more deadly and destructive, more objective, targeted and its acquisition and development are made more possible.

Although many are the possible causes of armed conflict, it is found throughout history that the religious together with the political were the main reasons for the beginning of many disputes. In Greece, the ruling the law of retaliation and war was a response to the violation of sacred laws. In Rome, in its turn, wars were fruits of violations of positive law. In the Middle Ages, already consolidated in Christianity, had the conflict represented by the Barbarians and Huns, keeping the Christian faith as a pillar. Religious and politics were also involved in the conflicts. 
It is only in modern times that the war takes more defined contours and acquired the concept of just war. In these times, there also was the division of the Church and with the weakening of the papacy what let some religious wars happen. Only with the Peace of Westphalia that war became lay.

Some centuries after, with the Contemporary Age war went through some changes: this new fighter, also called "human-soldier", is a new man, not just a combatant, but a person who defends his country with passion, as could be seen in the French Revolution (1789). The spirit of fight was inside of the citizens, who also defended its nation with its soul and love. They were not more a "soldier", a man who went to a war to kill enemies but a man who would fight for his passion.

It is clear that each conflict had a different historical period motivation and on the face of it, there is the difficulty to characterize a concept set for it. What is known is the differentiation between armed conflict and war, according to the Hague Convention [6]. But it is no consensus among researchers about an exact definition of war and the reasons why it occurs.

\section{Humanitarian Law: Principles and Liability}

International humanitarian law (IHL) can be defined as the set of international standards to be applied in armed conflicts, international or non-international and restricting the right of belligerents to choose the methods and means used in war and also protects civilians that can be affected by the conflicts [7]. In a vision lato sensu, international humanitarian law can be understood as a set of international legal provisions, written or customary, to ensure respect for the human person compatible with public order and, in wartime, the military order [8].

However, as the concept of war, there is a difficulty in establishing an accurate definition without gaps for the international humanitarian law. The International Committee of the Red Cross (IRCR) that was created in 1864, contributed for decoding of the law of war, acting as a non-state organization.

Henri Dunant established the predecessor of the independent International Committee of the Red Cross in 1863, and paved the way for the 1864 Convention for the Amelioration of the Condition of the Wounded in Armies in the Field. This document constitutes the first international convention on international humanitarian law. Before 1864, the rules on warfare were generally unwritten and based on custom. After 1864, many rules laid down were in a large number of conventions on a wide variety of topics.

Both the object and purpose of warfare and the ratio behind the laws of war were recognized by the drafters of the 1868 St. Petersburg Declaration. The St. Petersburg Declaration constitutes the first modern prohibition of the use of a specific weapon under international law by renouncing the use of the newly invented then type of rifle ammunition that exploded or ignited upon impact and which had been adapted for anti-personnel use. Because of its devastating effects upon troops, its use was considered undesirable in times of war between 'civilized nations' and not in conformity with basic requirements under the laws of war [9].

In 1899 Hague Conference was first adopted the Martens Clause, that is contained in the Preamble of the 1907 Hague Convention IV. The Martens Clause is considered the foundational principle of IHL and of environmental protection in the absence of other provisions. In this case, the Martens Clause stipulates that States should respect to the minimum established by the standards of "humanity" and the "public conscience" [10]. The Martens Clause broadens the range of applicable governing rules conduct during an armed conflict beyond those are laid out in the treaty instruments, by stating: "until the more complete code of the laws of war has been issued, the high contracting parties deem it expedient to declare that, in cases not included in the regulations ADOPTED by them, the inhabitants and the belligerents remain under the protection and the rule of the principles of the law of nations, as they result from the usages established among civilized peoples, from the laws of humanity, and the dictates of the public conscience.

The balance between military necessity and humanitarian values forms the foundation of ius in bello. Make up the ius in bello the following principles: humanity, necessity (discrimination and proportionality) and the environmental protection.

Humanity: It has its origins in the "laws of humanity". It is related with all aspects of behavior in armed belligerents Conflicts.

Necessity: Requires that military action shall only be employed in order to submit or weaken the military forces of the enemy, distinction shall be made between military and civilian objects and collateral damage to civilian objects must be kept to a minimum intervention. It is divided in appropriateness and proportionality, that means the limits of how far and how much the belligerents can be.

Environmental protection: Koppel brings the environment protection the ius in bello the principle because it has influenced the development of the laws of war [11]. It comes with the Stockholm Convention of Environment (1972) and is reflected in 1977 with the Additional Protocol I of Geneva Conventions (1949). These treaty rules were established in view of international concern for the use of certain means and methods of warfare during the war in Vietnam and since them they cannot be reduced to the principle of necessity either, or the principle of humanity, the existence of a new and third fundamental principle of ius in bello, focused on environmental protection, must be assumed. 
It must be mentioned that International humanitarian law is based on four sources:

Treaty law: International treaties, protocols and similar instruments that have been negotiated and ratified by participating States, including the four Geneva Conventions of 1949 and Additional Protocols I and II of 1977, the ENMOD convention of 1976 prohibiting environmental modification techniques, and the number of other specific conventions and protocols dealing with various aspects of warfare, such as limiting or prohibiting biological, chemical or nuclear weapons.

Customary law: Shared international rules established through widespread and uniform State practice, under the general belief that particular obligations bind all States, in contrast with treaty law, which applies only to those States who expressly consent to the respective treaties. In this context, customary law includes the norms of jus cogens from the derogation of which is permitted, and severe breaches of the IHL defined in the Geneva Conventions and Additional Protocol I.

Soft law: Rules that arise from action taken by international bodies such as the United Nations, including resolutions, decisions, codes of conduct and guidelines. By nature, soft law is not legally binding, though principles articulated in the UN General Assembly or Security Council resolutions with widespread acceptance may be recognized the customary international law. To the extent that they are recognized such, their provisions are binding on all States.

Case law: Decisions taken by judicial bodies at national or international levels, which are helpful for treaty interpretation or the evidence of customary law, as well as for assessing the practical gaps in the existing provisions of IHL governing environmental protection during armed conflict.

\section{Stockholm, Geneva and Rome}

Stockholm Convention: The concept of "sustainable development" was first written down with the Stockholm Convention in 1972. In this convention, two topics were mainly discussed: economic growth and environmental protection and how both could go together. In this occasion it also was defined, for the first time, "the limits of economic rationality and the challenges that environmental degradation leads to the civilizing process of humanity" [12].

The concern for the environment had already started earlier, in the 60's due not only of ecological accident large proportion, as Minamata-Japan, and the sinking of the oil tanker Torrey Canyon, but also the negative consequences of heavy industrialization, mainly pollution, which now compromise the well-being of the middle and upper class.

Amid this scenario of concern for the environment, it was released the document "The Limits to Growth" by the Club of Rome, which brought together scientists, academics, industrialists, economists and members of public institutions of developed countries, whose central topic of discussion was the concern with the environment, demonstrating that not only an alternative portion of society was aware of this issue, but the great decision makers too. This Club proposed a pessimistic view about the progress of industrialization, suggesting that the society of the time was headed for destruction, as it was worth the guided development model in the inordinate use of natural resources. This view was further aggravated by the theories of Thomas Malthus, which proposed that the growth of the world population would exceed the possibility of food production [12].

The first session of the Preparatory Committee, already checked the dissatisfaction of member countries about the direction of Stockholm, was based on the recommendations and topics that were raised in the conference preparation. In subsequent sessions, such discussions resumed, which led to the elaboration of a draft agenda for the conference where the Declaration of the Human Environment was discussed. This statement, however, was widely discussed at the Conference itself, since the 110 participating countries; only 27 were present at the Preparatory Session.

The trigger of the discussion was focused on thesis published by the Club of Rome then, "The Limits to Growth" and "Blueprint for Survival", which dealt with the issue of population growth, development and the environment, and that a flexibility of developed countries, which were not willing to accept the terms that seemed harmful to them [10]. Although some objectives have not been successful, this conference was a milestone in the awareness that the preservation of the environment depends on the cooperation of all countries.

The concept of sustainable development, in order to preserve now for access to natural resources for future generations, which derived the principle of intergenerational equity, treated in 1972.

According the principles of the Stockholm Declaration, man has the fundamental right to freedom, equality and adequate conditions of life, in an environment of a quality that permits a life of dignity and well-being, and he bears a solemn responsibility to protect and improve the environment for present and future generations. Still, the natural resources of the Earth, including the air, water, land, flora, fauna and especially representative samples of natural ecosystems must be safeguarded for the benefit of present and future generations through careful planning or management, as appropriate. The capacity of the Earth to produce vital renewable resources must be maintained and, wherever practicable, restored and improved [13].

In this hand, the States have the sovereign right to exploit resources their own pursuant to environmental policies, and the responsibility to ensure that activities within their jurisdiction or control of the causes damage to the environmental of other States or of areas beyond the limits of natural jurisdiction. 
It is found that in the 60's had a concern with the environmental issue, which was made official in Stockholm, with the conclusion of the Conference in 1972. One of the great achievements with this event was the establishment of concern for the present and future generations. A principle that will guide future conventions, as well as the standardization hits of the environment, in all fields (national and international).

Also, since you saw the reflection of the United Nations Charter and the principles of IHL, when concern about the damage caused by States and their accountability and compensation to the victims of the harm suffered.

Once existing concern about the future environment, that is, the one destined to future generations, we must ensure their preservation, in all forms, including during armed conflict.

Additional Protocol I to Geneva Conventions: The Additional Protocol I of Geneva Conventions of 1949, created in 1977, applies to international armed conflict and contains two specific provisions for the protection of the environment, including prohibits attacks on the environment to such, regardless of the means used.

Although it is a milestone regarding war crimes, the methods of warfare directed against the ecology and environment became matters of concern treaty before the twentieth century with the military codes.

In the Additional Protocol I, it can be found two articles which express the environment concern: articles 35, in the Basic Rules, and 55, contained in the Protection of the natural environment section [14]. The article 35 basically determines that in any armed conflict, the right of the parties to the conflict to choose methods or means of warfare is not unlimited, which means that the belligerents are not allowed to use any gun or method that they want. Also, the article points that it is prohibited to employ weapons, projectiles and materials and methods of warfare of a nature to cause superfluous injury or unnecessary suffering, what shows a concern with the extension of practices and methods applying while a conflict. And finally, it says that it is prohibited to employ methods or means of warfare which are intended, or may be expected, to cause widespread, long-term and severe damage to the natural environment, that demonstrates the environment got an specific protection under the law, even it is vague and without a definition of "severe damage".

Beyond this article, the Additional Protocol I also contain another important statement: article 55. It determines that care shall be taken in warfare to protect the natural environment against widespread, long-term and severe damage. This protection includes a prohibition of the use of methods or means of warfare which are intended or may be expected to cause such damage to the natural environment and thereby to prejudice the health or survival of the population. And it also points that attacks against the natural environment by way of reprisals are prohibited.

Although the article 35 of Additional Protocol I prohibits the use of "methods or means of warfare which are intended, or may be expected, to cause widespread, long-term and severe damage to the natural environment. Using the same language, Article 55 aims to protect the population, whose health and survival in the event of armed conflict could be endangered by damage to the environment. The article also prohibits attacks on the natural environment by way of reprisals.

It is understood then that any belligerent nation can cause damage to the environment in their actions, as little use as a reprisal, environmental damage. The response of an act must be proportional to, as has the principle of proportionality, which governs the International Humanitarian Law.

But still there is a perceived gap in these devices because there is the need to adapt as well as new international agreements for the protection of the environment during armed conflict. There is no available literature and case studies in large quantities, so little judged causes.

Estatute of Rome: The first attempt to establish an International Criminal Court was in 1872, with Gustav Moynier (one of the founders of ICRC), which would be composed of five members, two appointed by the belligerents and three neutral. But this initiative did not arouse interest at the time. Only after the Second World War there was the desire to create a permanent court, starting with Nuremberg, Tokyo, Yugoslavia and Rwanda.

However, these courts did not have permanent. Only in 1998 there was the agreement to implement the International Criminal Court, which was approved in Rome. It is composed by: president, attorney, secretary of first instance section, section of preliminary issues and appeals section. The criminal court consists of 18 judges, 10 criminalists and 8 internationalists without repeated nationality [15].

The International Criminal Court have jurisdiction over genocide, against humanity, war crimes and aggression (art 5).

Genocide: All acts committed with intent to destroy in whole or in part national, racial or religious groups. Still, according to art 6 of the charter itself, constitute genocide: killing members of the group, causing serious injury or mental group members; deliberately inflicting on the group conditions of life calculated able to bring about its physical, total or partial destruction; Imposing measures intended to prevent births within the group; forcibly transferring children of the group to another group. 
Crimes against humanity: Provided for in art 7 includes all acts committed with the intention of promoting a widespread or systematic attack against a civilian population. It does not need encompass all of it, but at least some of the individuals that make up the population. Examples: murder, slavery, rape, torture, sexual slavery, etc.

War crimes: The provision of art 8 is defined as one that is part of a pre ordained plan or a policy, or that are part of a criminal conduct committed on a large scale within that policy. Yet, they are serious breaches of the Geneva Conventions of 1949 , as an international murder, destruction of property not justified by the war and deportation.

Crimes of aggression: Or also called "crimes against peace". It was included in the Rome Statute by art 5, 2, but does not have a strict meaning given. Seeking a consensus among the signatory States to a setting that do not leave too large, in order to prevent abuse. Anyway, until the last summit neither member had signed it.

Among the penalties brought by the Rome Statute are: not imprisonment exceeding 30 years, life imprisonment, fines and confiscation of property.

The Rome Statute of 1998 incorporates some of the prohibitions contained in the Additional Protocol I. For instance, the future International Criminal Court will have jurisdiction in respect of war crimes that consist in intentionally launching an attack in the knowledge that such attack will cause incidental [...] widespread, long-term and severe damage to the natural environment which would be excessive in relation clearly to the concrete and direct overall military advantage anticipated [15].

The nation who causes some environmental damage during armed conflict, which means, if your attack or act against attack exceeds the limits of the principle of proportionality, they will be under the art 8 of the Rome Statute. Once the military objectives should not be targeted if the attack is likely to cause collateral environmental damage which could be excessive, it is exactly this "proportionality" that contains another problem: what can be the considered an excessive damage?

Even the art 8 could define precisely what an important violation is and it has been seen in every document about this issue: the lack of concepts and strict definitions to guide nations and courts to understand what is allowed or not and how to prosecute who exceed the limits and cause some environmental damage in an armed conflict.

\section{The XX Century and its Conflicts}

The Water Aim the damages caused in armed conflicts or wars are very dangerous and can be extended for some future generations. These will suffer with diseases, land and soil problems, and modify food or a lack of any kind of them. Agent Orange, land mines, nuclear weapons, weapons deposited on the ground, are just some of the problems left by the belligerents to the environment.

When it is considered the water as the most necessary resource for the human life, a pre-condition for the human existence, it could become in a powerful gun to good and worst: lives can be saved and nations can be destructed.

Water can be the reason of cooperation or a reason and cause of a conflict, says Jan Elyasson, Deputy Secretary General of United Nations [16].

According to the United Nations, approximately 40 per cent of the world's population lives in river and lakes basins that comprises two or more countries, and perhaps, even more significantly, 90 per cent lives in countries that sharing basins. A total of 148 States include territory within the basins and 21 lie entirely within them [17].

It is a large number of civilians and environments included in this statistic. Considering everything that water is able to provide and how much it can interfere in social, cultural, geographic and political aspects, it can become in a powerful gun.

Since long time ago, armed conflicts have been seen in the history and its motivations are always political, geographic, power or religion. And as it could be showed in this article, they are increased more and more. Nowadays, the most common conflicts are about religion and political issues and many of them are occurring in important water transboundary areas as Nile, Tiger and Euphrates River.

Zeitoun explains that there is a belief, for example, that in regions with growing populations, unstable governments and dwindling water resources, war over water at some point is highly probable. In semi-arid zones such as the Middle East, the likelihood of a conflict over water is compounded by historic and existing political, national and religious tensions in the region. A water war between Israel and Palestine, Egypt and Ethiopia or Turkey and Iraq - in this simple Malthusian logic - would seem inevitable [18]. He also mentions that there is some evidence that tends to support the idea that Jordan River, for example, influence in the 1967 war between Israel and Syria. Even this case was not proved, Zeitoun also says that there is certainly reason to be concerned over Egyptian threats over the Nile or the effects of Turkey's damming of the Tigris and Euphrates [18].

In 2001, there was a situation that obligated Iraqi water engineers keep up some changes, because the flows had been dammed, the river had become increasingly shallow, and had begun to pull away from its bank and the original intake structure. The engineers were obliged to extend the intake structure 50 meters in towards the river to find a deep enough spot to draw water off from. The more the rivers dried up, the further the engineers are obliged to extend the intake structures. It is a myopic engineering response 
to an environmental 'challenge' engendered by an international transboundary water conflict. The wetlands at the confluence of the Tigris and Euphrates had furthermore been drained by the ruling Iraqi Ba'ath party sometime in the 1990s, destroying once and maybe for always the lives and lifestyles of the Mada'an people (the so called Marsh Arabs). This is a domestic water conflict.

And there are others kind of conflicts related to water but what must be highlighted is the fact that if its scarcity or its contamination are problems that should be concerned. Thus water is an integral part of war-usually as a target, sometimes as a weapon but seldom as sole motive. Since there are no deaths related to water, they concur, there is no problem, no conflict [18].

However, some deaths will be occurred some years after the damage. Whether be considered the use of mass weapons during a conflict, the damages that they can cause are powerful. Indeed, it could be worst if the damages were caused by chemical weapons and buried nuclear material, no deactivated landmines which are left in soil (near aquifers or rivers springs), armaments and munitions destroyed in the soil, not to mention the effects of some weapons when used (uranium, agent Orange, etc).

There is no report which mentions about this liability: water contamination during an armed conflict and more, about the control of a possible water contamination with destruction interests. If none international document talk about this subject, there is a gap that could become in a terrible problem not just for the environment but also to the nations.

Some belligerents do not intend use the water as a gun because they will be suffers too. But what must be considered it is the fact that there is no environment protection in this case and even worst, humanitarian and international law do not mention the liability and punition in this scenario.

Some tensions where water supplies or access to water is at the root of the tensions, are able to illustrate how important is this issue. For example, water as a Political Tool where water resources or water systems are used by a nation, State or non State actor for a political goal: Egypt-Sudan 1958; Israel-Syria 1958; Brazil-Paraguay 1979. Iraq-Syria 1974; water as a tool for terrorism where water resources, or water systems are used by a non-State actor as tools of violence or coercion: Turkey-Syria-Iraq 1990; Malaysia-Singapore 1997; water as a military tool where water resources, or water systems themselves, are used by a nation or State as a weapon during a military action: East Timor 1999; Kosovo 1999; Israel, Palestine 2001; Nepal 2002; US-Iraq 2003; water as a military target where water resource systems are targets of military actions by nations or States: Ethiopia-Somalia 1948; Israel, Lebanon 1982; Bosnia 1992; Kosovo 1999; US-Iraq 2003 [19].

Some of the important international rivers, that are the subject of this article, Nile, Euphrates and Tigris, and the States that are within basins, Ethiopia, Sudan, Egypt, Turkey, Syria and Iraqi, show the possibility to understand how the gaps must be solved and the liability for belligerents which cause the damage while the welfare must be observed.

\section{Conclusion}

An armed conflict should always be avoided, however, if it is not possible, its damage must be calculated and prevented.

Although there are some international documents which give some protection for civilians and the environment while the armed conflict, there is still some gaps concerned the liability of the belligerents.

The Stockholm Convention, the Additional Protocol to the Geneva Convention and the Statute of Rome, documents that were chosen to be part of this study, do not express specifically about the environment protection in armed conflicts or war. They are vague and contain a lot of lacks which can turn against the environment and the civilians and do not guarantee their protection.

When guns, chemical weapons, landmines and missiles are used, a lot of chemical remains stay in the soil and water and they can cause damages a long term for the environment. It is proved, along de history that the problems caused by the use of weapons are substantial and considering the increasing of conflicts since last century, they just tend to get more powerful and destructive.

Considering the water as a resource essential for the life and its importance social-political and geographic, especially about the transboundary fact, the water can become in a powerful way of destruction, since its lack until the contamination (intentional or not).

It is necessary a better and complete protection to the environment during the armed conflict, what must contains the liability of the belligerents which cause an environmental damage, as well as the specification of "damage" and its proportion. Punishing the States which compromise the land and water health and, of course, the civilians who depends of them to survive.

\section{References}

1. A. Montagu (2014) A natureza da agressividade humana. Rio de Janeiro: Zahar Editores 11-2.

2. Green LC, State responsibility and civil reparation for environmental damage in International Law Studies, Volume 69. Protection of the Environment During Armed Conflict, 416-7.

3. Mello C (1997) Direitos humanos e conflitos armados. Rio de Janeiro: Renovar, transl by the author.

4. Spanier J (1996) Games nations play. Congressional Quarterly Press.

5. Tilly C (1996) Coerção, capital e Estados europeus. São Paulo: Edusp transl by Geraldo Gerson Souza, 126. 
6. Hague Convention IV, Respecting the Laws and Customs of War and Land (with Annexed Regulations), 18 Oct. 1907.

7. Swinarski C (1988) Introdução ao direito humanitário internacional. Brasilia: Escopo, 18, transl by the author.

8. Pictet J (1986) Le droit international humanitaire: definition, in Les Dimensions Internationales du Droit Humanitaire. Paris: Institute Henry Dunant e UNESCO 04 .

9. Young M (1989) The Techincal Writers Handbook. Mill Valley, CA: University Science.

10. Duncombe JU (1959) Infrared navigation-Part I: An assessment of feasibility (Periodical style). IEEE Trans Electron Devic 11: $34-9$.

11. Koppe E (2008) The use of nuclear weapons and the protection of the environment during international armed conflict. Oregon: Hart Publishing 109.

12. Dombrowski V (2011) Practical-theory aspects of urban environmental Law. Dissertation. Florianópolis: Federal University of Santa Catarina 35.

13. United Nations Declaration on the Human Environment, Stockholm, 1972.

14. Protocol Additional to the Geneva Conventions of 12 August 1949, and relating to the Protection of Victims of International Armed Conflicts (Protocol I), ILM 1391, 1997

15. Statute of Rome (1988) article 8, para 2 [b, IV].

16. UN-Water (2015) World Water Day.

17. UN Water (2008) United Nations Inter-Agency in mechanism in all fresh water related issues including sanitation. Transboundery waters : UN-Water paper sharing benefits, sharing responsability. UNESCO, 2013.

18. Zeitoun M (2008) Power and Water in the Middle East : The Hidden Politics of the Palestinian-Israeli Water Conflict. London, GBR: I.B. Tauris, ProQuest ebrary, April 2015: 4-7.

19. Gleick P (2003) Water Conflict Chronology - Introduction, Pacific Institute, August.

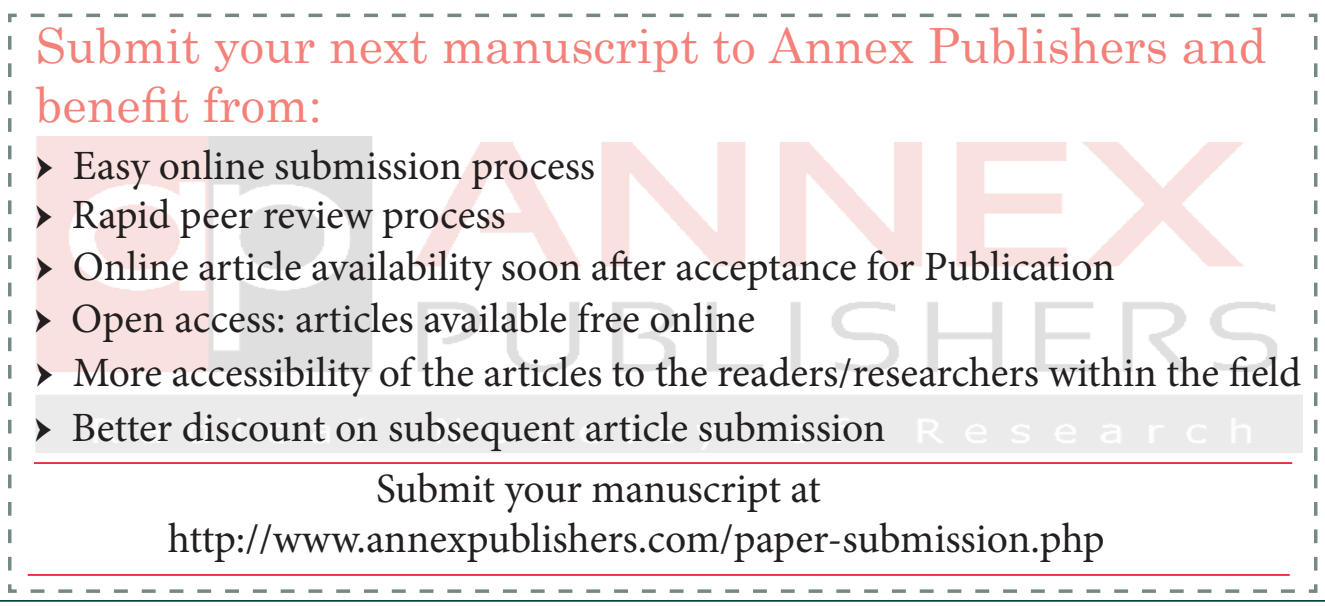

